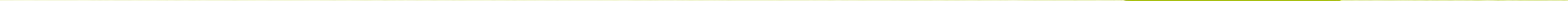




\title{
The two faces of reputation risk: anticipating downside losses while exploiting upside gains
}

\author{
Charles J. Fombrun
}

- Professor Emeritus of NYU's Stern School of Business where he was on the standing faculty from 1984 to 2004

- Professor of Management at The Wharton School from 1979 to 1984

- Author of numerous books, including the best-selling Reputation: realizing value from the corporate image

- Published hundreds of articles and is the creator of reputation tracking systems used by many companies around the world

- CEO and Founder of Reputation Institute

- cfombrun@reputationinstitute.com

Kasper Ulf Nielsen

- Engaged in international reputation management since 2000 helping companies in a range of industries such as Pharmaceuticals, Information Technology, Food and Beverage, Public Transportation, and Financial Services

- Managing Partner of Reputation Institute responsible for client engagements in North America

-knielsen@reputationinstitute.com

Nicolas G. Trad

- Coordinates Reputation Institute's global network and works closely with clients all over the world

- Led reputation projects for companies all over the world and is a featured speaker at conferences and seminars focusing on reputation management

- Managing Partner of Reputation Institute and Director of International Operations

-ntrad@reputationinstitute.com

\begin{abstract}
About Reputation Institute - www.reputationinstitute.com Reputation Institute (RI) is the leading organization providing professional assistance to companies interested in managing their reputations proactively. Founded in 1997, RI has been and remains the pioneer in advancing knowledge about corporate reputations and developing management tools enabling companies to create value from their reputation.
\end{abstract}




\section{Resumo}

Este artigo examina a natureza ambígua do risco da reputação e discute como as empresas lidam com a dualidade da gestão da reputação. Ele também exibe ferramentas desenvolvidas pelo Reputation Institute que auxiliam na identificação e no gerenciamento de ameaças e oportunidades com as quais empresas se deparam na gestão de suas reputações, facilitando, assim, o processo de tomada de decisão.

PALAVRAS-CHAVE: REPUTAÇÃO CORPORATIVA

\section{Abstract}

This article examines the Janus-faced nature of reputation risk and discusses how companies address the duality of reputation management. It also showcases a decisionmaking tool developed by Reputation Institute that companies are now using to help identify and address the largest threats and opportunities they face in managing their reputations.

KEYWORDS: CORPORATE REPUTATION

\section{Resumen}

Se investiga la naturaleza ambigua del riesgo de la reputación y se discute cómo las empresas reaccionan ante la dualidad de la gestión de la reputación. Abarca, además, las herramientas desarrolladas por el Reputation Institute, que contribuyen a la mensuración y gestión de las amenazas y oportunidades con las cuales las empresas se deparan en la gestión de sus reputaciones, facilitando, así, el proceso de toma de decisión.

PALABRAS CLAVE: REPUTACIÓN CORPORATIVA 
Companies are challenged with maximizing the value of their intangible assets. On average, intangibles account for over $65 \%$ of the market value of most public companies. Managing intangibles, however, has two facets: on one hand, it requires capitalizing on opportunities to build a company's intellectual capital, brands, and reputation; on the other, it calls for actions that help the company minimize the risk of market value losses that could occur from scandals, crises, or other sources of reputation loss. A survey conducted by the Economist Intelligence Unit (2005) found that in a large sample of senior international managers, $90 \%$ said that "reputation" was among a company's most valuable assets. It confirmed other findings suggesting that senior risk managers considered "reputation risk" to be the most significant threat companies now faced.

\section{The two faces of corporate reputation}

Handling negative criticism is the job of a growing number of communication executives who specialize in managing crises. Of primary concern to them is a desire to minimize damage to the company's stock of reputation capital - the value of the company's intangible assets, a number that constitutes about $65 \%$ of an average company's market value, and that accounts for over $90 \%$ of the market value of many celebrated companies like The Coca-Cola Company and Google.

Reputation capital is the part of a company's market value that is regularly "at risk". It grows when managers convince reporters and analysts to praise the company and recommend its shares. It is destroyed when stakeholders lose faith in the company's managers, products, or prospects.

The C-suite tends largely to view risk in the context of "losses" (FOMBRUN, GARDBERG \& BARNETT, 2000). Without an effective system that enables the company to address stakeholder collisions with strong leadership, good decisions, and timely communication, reputation capital built over many years can evaporate in an instant.

The Aon survey (2007) we referred to earlier was conducted in 320 large global companies. The results indicate that of the top 10 corporate risks managers see today, "damage to reputation" has the highest threat to value. As the report points out, damage to reputation is an enterprise-wide event that can lead to lowered stakeholder support, decline in financial performance, and a loss of goodwill with local communities as well as its "license to operate" in key markets (MCDOWALL, 2005). 
Though significant, focusing solely on the threat of loss, however, ignores the other side of reputation, namely the very real potential that a company has to generate gains by capitalizing on the hidden opportunities that are inherent in risky situations (MENDONCA \& OPPENHEIM, 2007; ROBERTS \& DOWLING, 2002). Doing so is encouraged by a silo-mentality in most companies that separates "crisis management" from reputation-building activities - what we call "reputing" - and thereby decouples the two sides of the risk equation.

Although "damage to reputation" tops the list of risks identified by senior managers, fewer than $50 \%$ of them claim to have a strategic plan in place for managing reputation risk. We argue here that mitigating these risks requires implementation of a systematic Reputation Management Process that begins with measurement of reputation.

Senior managers and boards have found it difficult to develop a sound system for managing reputation risks because they have lacked a reliable and consistent measure of "reputation" itself. Although a wide variety of measurement tools have been developed over the past twenty years, there has been limited convergence around a single definition and instrument. In our view, it's high time convergence took place.

Reputation Institute defines "reputation" as the degree of trust, admiration, esteem, and good feeling that stakeholders have for a company. The definition is based on extensive qualitative and quantitative research from more that 25 countries conducted jointly with the member companies of Spain's Foro de Reputacion Corporativa (http: / / www. reputacioncorporativa.org) that confirms that these emotional attributes are the anchors that guide people's perceptions of companies with higher or lower reputation.

Through rigorous statistical analysis, Reputation Institute has demonstrated that a company's reputation typically rests on a combination of attributes grouped around seven key dimensions: Products/Services, Performance, Innovation, Workplace, Citizenship, Leadership, and Governance. This is captured in the RepTrak ${ }^{\mathrm{TM}}$ Scorecard, a standardized tool for reputation measurement that is now in widespread use by many major companies around the world (see figure 1). 


\section{Figure 1}

\section{The RepTrak ${ }^{\mathrm{TM}}$ Scorecard}

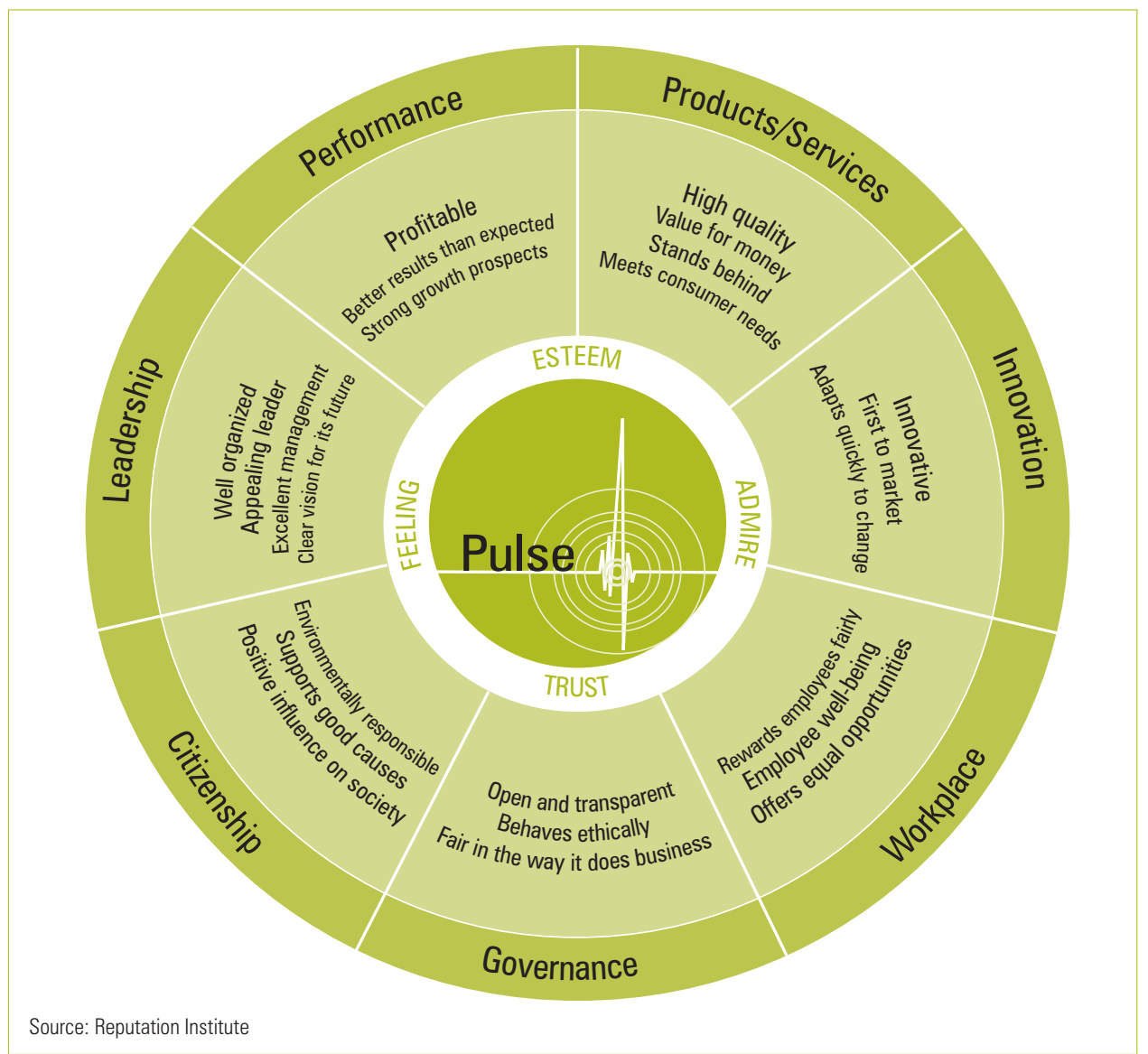

The RepTrakTM Scorecard is typically customized to the strategic context of a company, while retaining its overall comparability to the standardized model. Doing so enables systematic measurement and comparative analysis of perceptions across stakeholder groups, across market segments, across demographic or psychographic segments, across countries, and over time.

Ultimately, reputation is part of a cycle through which financial value is either created or destroyed. A crisis can launch a downward financial spiral that triggers serious financial problems, including underperformance, declining earnings, and liquidity and cash-flow blockages. It can also unleash a host of non-financial challenges, including a loss of confidence, pressure from stakeholders, suppliers and customers, regulatory scrutiny, and demoralized staff. A downward spiral, however, is not 
inevitable. Early detection and swift, decisive action can mitigate the crisis and help senior managers regain control, restore performance, and rebuild value.

An effective system for reputation risk management should therefore consist of two key processes that work together:

\begin{tabular}{|c|c|c|c|c|}
\hline $\begin{array}{l}\text { Effective Reputation } \\
\text { Risk Management }\end{array}$ & & $\begin{array}{l}\text { Minimizing } \\
\text { threats of loss } \\
\text { ['Anticipating'] }\end{array}$ & + & $\begin{array}{c}\text { Maximizing } \\
\text { gain opportunities } \\
\text { ['Reputing'] }\end{array}$ \\
\hline
\end{tabular}

Defending reputation capital: the anticipating process

Companies need accurate tools for judging the likelihood of particular events that could destroy their reputation capital. A RepTrak ${ }^{\mathrm{TM}}$ risk assessment unfolds in two parts:

Identify driver weights: how much influence do the RepTrak ${ }^{\mathrm{TM}}$ attributes and dimensions have on the company's overall reputation? Knowing the relative weights enables prioritizing events that have the highest likelihood of influencing the company's reputation, and so to threaten the value of its reputation capital.

Identify the likelihood of media coverage: how likely is a particular event to create negative media coverage? Research shows that reporters and analysts are more likely to pick up on certain types of events than others. If the media writes a lot about a specific issue the risk for reputation loss is higher than if the story only gets limited media coverage. By understanding what the media is focusing on, the media visibility of specific risks can be identified.

Novo Nordisk is a global pharmaceutical company from Denmark that is specialized in the treatment of diabetes. The company has a strong commitment to sustainability and to "ensuring a superior company reputation", and these ideas have worked their way into the company's business model (see figure 2). Considering the importance Novo Nordisk places on their reputation and the efforts they put into maintaining it, it should come as no surprise that senior executives in the company are especially concerned with reputation risk. The model shows that they believe that a strong reputation is a necessity for building a successful business. The company believes that a solid and lasting reputation in an industry like pharmaceuticals that is under constant scrutiny, gives it a competitive advantage that the competition finds difficult to match.

As Mike Rulis, vice president of Corporate Communications, puts it: "Acknowledging that the loss of reputation is a key business risk has been an important step in integrating reputation into the strategy process. However, the problem we face is that we start seeing reputation risks everywhere and get paralyzed because it's hard to say which risk we should act on". 


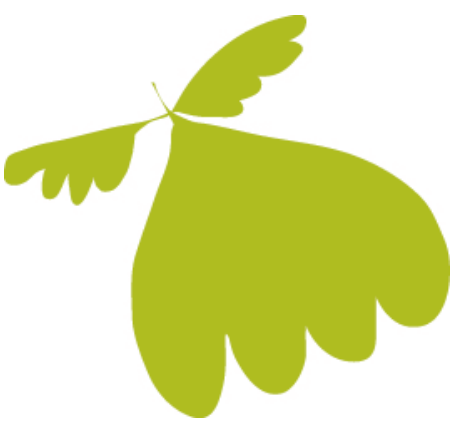

Novo Nordisk adopted a RepTrakTM based Reputation Risk Tool in 2007. The process involved examining market research data from a cross section of stakeholders, including physicians, employees, financial analysts, and patients using the common lens of the RepTrak ${ }^{\mathrm{TM}}$ Scorecard. Doing so led to identification of common driver weights for use in predicting the likely impact of key events. Major media articles were then coded for their positive and negative effects on each of the reputation attributes. It enabled deriving a profile of the likelihood with which events that took place in the pharmaceutical industry were likely to get favorable or unfavorable coverage in the media.

The results of these analyses were incorporated into an interactive online system that now enables managers involved in risk management at Novo Nordisk to input locally occurring events and to aggregate them into a shared risk profile for the company as

\section{Figure 2}

How Novo Nordisk integrates reputation into

the company's business model

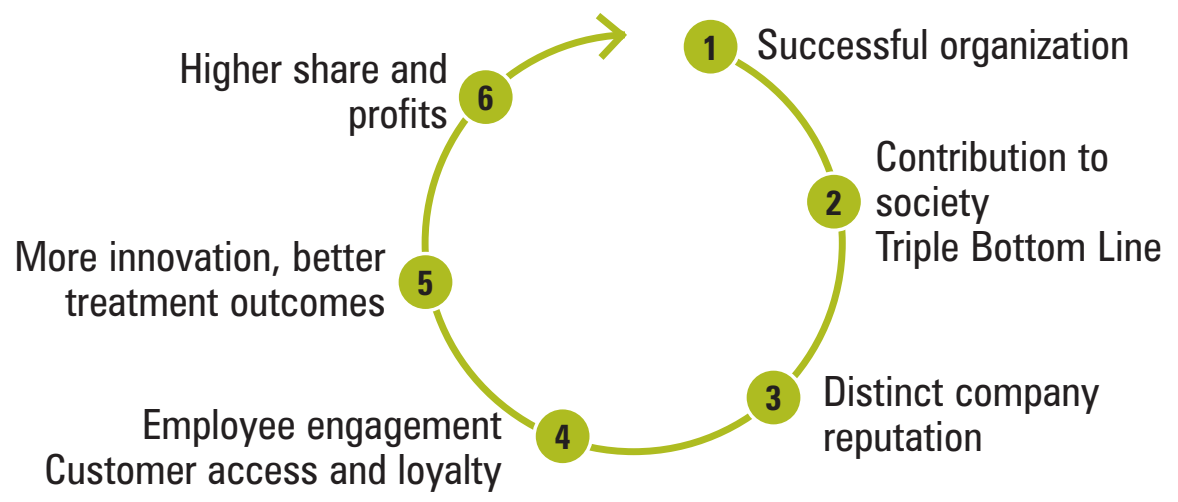


a whole across business units and markets. Doing so has enabled simplifying and consolidating the process of anticipating reputation risks, assessing their likely impact, allocating resources to addressing them, and prioritizing responses.

There are two key results derived from the online tool. The first is illustrated in figure 3 and shows the current state of the "total risk" position of the company. It facilitates dialogue among decision-makers about the current risk profile of the company compared to its "desired state".

The second result of the system is a set of charts that enables the company to see the probable effect an event would have on the company's different stakeholder groups. This is especially important when assessing risks that affect stakeholder groups differently. Multiple events can be plotted together to create a consolidated risk profile, highlighting that events could have the greatest negative effect on each stakeholder group. The visualization of risks is helpful in facilitating a conversation among decision-makers about alternative courses of action.

Finally, the tool also provides companies with a way to identify the impact of risk multipliers. Figure 4 shows a screen shot of the RepTrak ${ }^{\mathrm{TM}}$ Risk tool, and the likely range of effects on media coverage and on stakeholder perceptions that a combination of events might have.

According to Mike Rulis: "We were spending a lot of time inside Novo Nordisk discussing issues based on each person's gut feelings. By having a system that identifies what is most important to our different stakeholders we have a common language and a common platform to speak from, and it helps us make better decisions. Now we use the data to argue from while still using our personal experience and judgment to make decisions. We don't believe that we have found the perfect answer because reputation management is in constant development and there will be issues that we didn't foresee as dangerous that will actually become crises. This system helps us reduce the risk/chance that we will miss a major issue/opportunity".

\section{Building reputation capital: the reputing process}

To capitalize on the positive side of the reputation value-cycle, savvy companies invest in the "reputing process". Reputing consists of a wide range of initiatives designed to build and protect reputation, and can be defined as the actions and communications that make you relevant to your stakeholders.

Understanding what stakeholders want from the company is critical in creating trust, admiration, esteem, and good feeling. An outside-in perspective is required to understand how to make the company relevant to its stakeholders. The "reputing process" 
THE TWO FACES OF REPUTATION RISK: ANTICIPATING DOWNSIDE LOSSES WHILE EXPLOITING UPSIDE GAINS

- charles J. fombrun - kasper ulf nielsen - nicolas g. TRAD

Figure 3

Defending reputation capital - the anticipating process

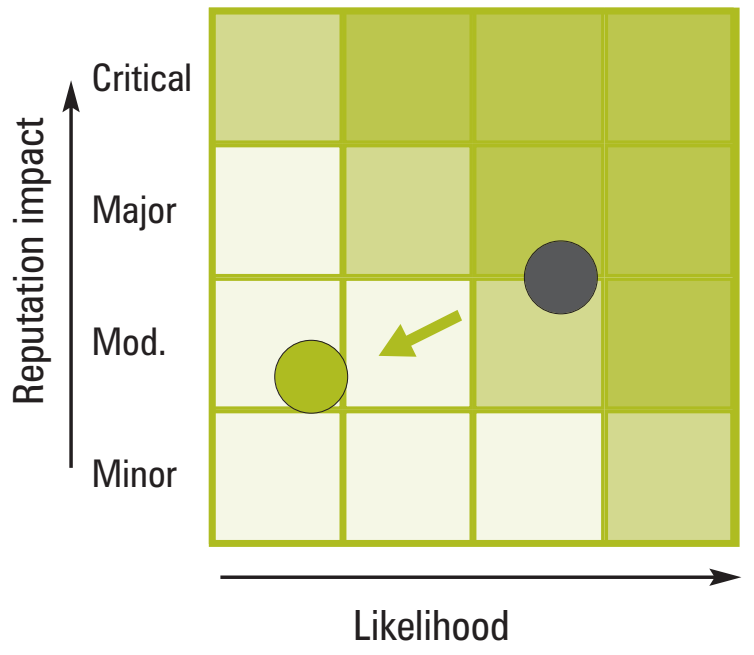

Current State

Desired State

Figure 4

Screen shot of RepTrak ${ }^{\text {TM }}$ risk tool

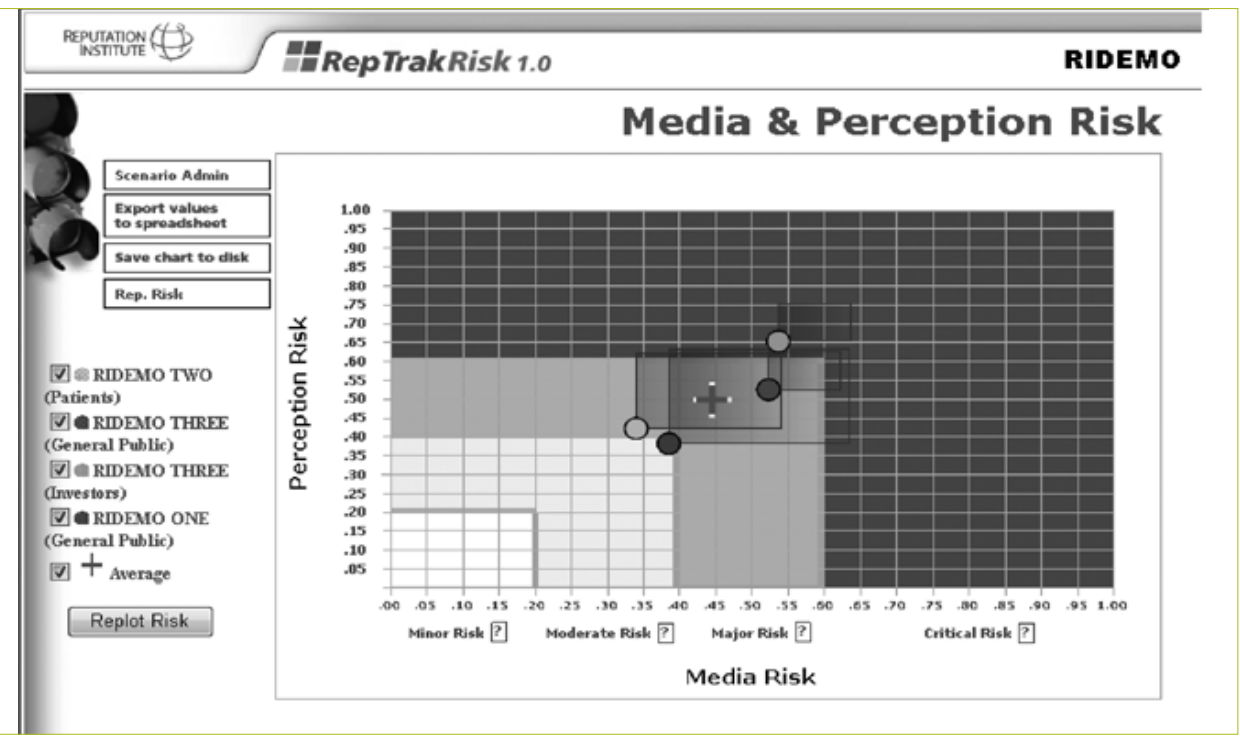


THE TWO FACES OF REPUTATION RISK: ANTICIPATING DOWNSIDE LOSSES WHILE EXPLOITING UPSIDE GAINS

- charles J. FOMBrun • Kasper ulf nielsen • nicolas G. TRAD

involves a common sequence of steps that should be conducted in parallel with the "anticipating process":

Step 1 -Identification: identify those stakeholders whose perceptions are likely to have a significant impact on aggregate perceptions of the company.

Step 2 - Research: understand how those stakeholders perceive the company.

Step 3-Relevance: identify the attributes of the company that are most relevant to those stakeholders.

Step 4 - Profile: define what the company is currently doing and communicating regarding those attributes.

Step 5 - Expression: develop a coherent set of reputing initiatives around which to "express" the company to those stakeholders.

Step 6 - Engagement: work with key stakeholders through personalized actions and corporate communications.

Step 7 -Assessment: track the effects that the company's reputing initiatives are having on stakeholder perceptions.

Consider telecom giant Telefonica. In recent years, Spain's largest company has invested, not only in supporting a strong reputation tracking system, but in a $360^{\circ}$ reputing process for influencing its key stakeholders internationally. The company's 2007 reputing platform centers on the concept of "Espiritu de PROGESO" - the spirit of progress. The platform reflects Telefonica's technological core values and commitment to promote development of the local economies in which it operates internationally. That commitment is enacted through a wide range of initiatives and communications targeted to all of its stakeholders through reports, advertising, sponsorships, and through the philanthropic activities of the company's foundation.

As described in figure 5, Telefonica's Reputing Process places the emphasis squarely on the stakeholder. The process is inherently concerned with the actions and communications that the company has determined to be relevant to those stakeholders through close engagement on the ground. Its reputing process is equally about personal dialogue, listening, and understanding stakeholders as it is about communicating the corporate brand.

Ultimately, risk management is about both anticipating strategic issues and leveraging opportunities to engage with the company's key stakeholders around topics and initiatives that are most relevant to them. Effective risk management is about aligning perception and reality. A great reputation that is not grounded in reality is a catastrophe waiting to happen. A weak reputation that is not deserved is an opportunity to exploit.

In order to build trust, admiration, esteem, and good feeling for their companies, senior managers must engage in a process that actively engages with stakeholders on their terms. Developing an integrated system for enterprise-wide risk mana- 
THE TWO FACES OF REPUTATION RISK: ANTICIPATING DOWNSIDE LOSSES WHILE EXPLOITING UPSIDE GAINS

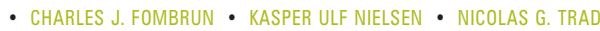

Figure 5

Building reputation capital: Telefonica's reputing process (2007)

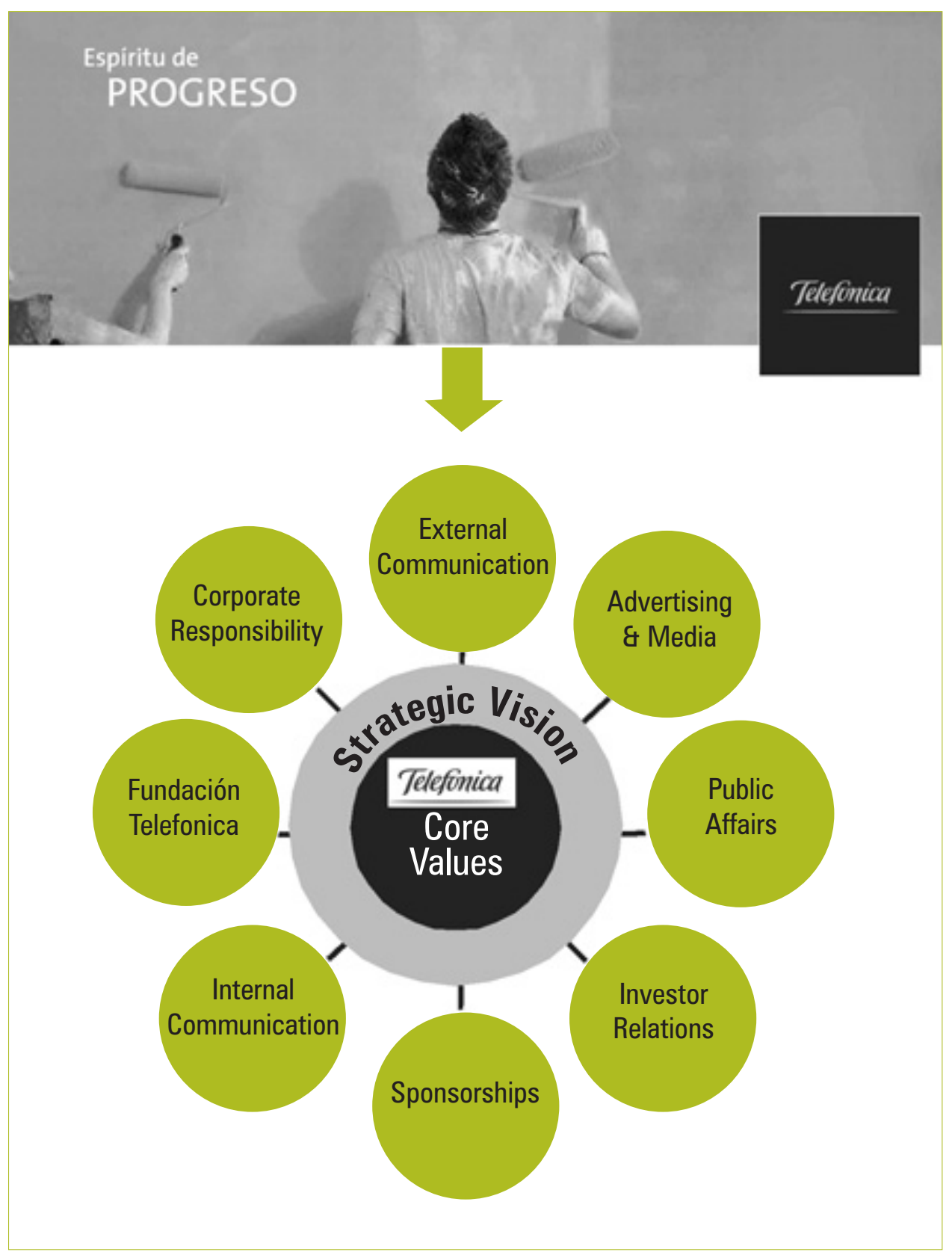


gement is the best way to ensure a healthy relationship with a company's employees and other stakeholders, and thereby maximize the long term financial value of the company.

\section{Organizing for reputation risk management}

Effective risk management involves considerably stronger integration among organizational functions that contribute to creating and defending a company's reputation capital (PETERSEN \& CARREAU, 2005). On one hand, reputation capital is enhance from a reputing process that builds value by investing corporate resources in building intellectual and reputation capital through corporate advertising and sponsorships, Public Relations, community involvement, and philanthropic initiatives. On the other hand, reputation capital is defended by the creation of a central risk office, identifying risk owners throughout the company that focus on looming threats, and consolidating "weak signals" about potential threats into a coherent whole that senior managers can rely upon to formulate strategic and tactical responses.

Having a reputation risk management structure that recognizes the duality of the reputation construct is invaluable to companies who want to manage their reputation capital. For companies like Novo Nordisk and Telefonica, recognizing the inherent value of a corporate reputation was a crucial first step. Investing behind a systematic process that enables managers to track reputation risks and opportunities is the crucial next step. The RepTrak ${ }^{\mathrm{TM}}$ Risk tool provides companies with a valuable decision-making tool for protecting the reputation capital these companies work so hard to create.

\section{References}

AON Corporation (2007). Global Risk Management Survey 2007.

ARNOLD, NOEL \& ASSOCIATES. How to manage reputation risk, Risk Review, 7 November, 2007.

ECONOMIST Intelligence Unit. Reputation: risk of risks, The Economist. 2005.

FOMBRUN, C.; GARDBERG, N.; \& BARNETT. M. Opportunity platforms \& safety nets: corporate citizenship and reputation risks, Business \& Society Review, 2000, 105: 85-106.

MCDOWALL, B. (2005) Reputational risk, The Register, 22 May, 2006.

MENDONCA, L. T. and OPPENHEIM, J. Investing in sustainability: an interview with Al Gore and David Blood, The McKinsey Quarterly, May 2007. 
THE TWO FACES OF REPUTATION RISK: ANTICIPATING DOWNSIDE LOSSES WHILE EXPLOITING UPSIDE GAINS

- Charles J. FOMBRun • KASPER Ulf nielsen • nicolas G. TRAD

PETERSON, G. E. and CARREAU, R. B. Managing reputation risk: creating an effective risk structure, 07 June, 2005. $<$ http://www.insurancebroadcasting.com/061705reputation.htm>

PRICEWATERHOUSECOOPERS. Predicting the unpredictable: protecting retail \& consumer companies against reputational risk, PricewaterhouseCoopers. 2005.

ROBERTS, P. W. and DOWLING, G. R. Corporate reputation and sustained superior financial performance, Strategic Management Journal, 2002, 23: 1077-1093.

WEBER SHANDWICK (2007). Safeguarding Reputation.

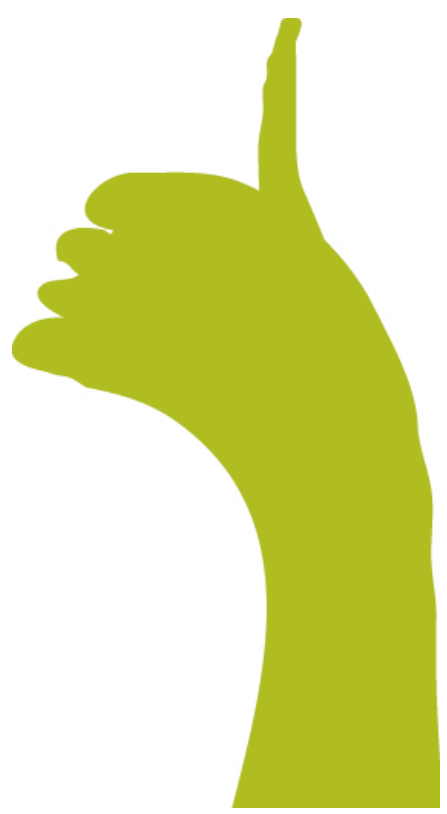

